\title{
THE IMPACT OF THE ECONOMIC ACTIVITIES OF MARINE TOURISM IN JANGKA BEACH, JANGKA MESJID VILLAGE OF JANGKA BIREUEN SUBDISTRICT, INDONESIA
}

\author{
Amri Saiful ${ }^{\star}$, Meilina Hesti, Nasir Muhammad \\ Master's Program of Integrated Coastal Resources Management, \\ University of Syiah Kuala, Indonesia \\ *E-mail: rizaramadhanbaron@gmail.com
}

\begin{abstract}
Jangka Coast Area, Gampong Jangka Masjid, Jangka Subdistrict is one of the tourist destinations in Bireuen Regency which has the potential to be developed. Jangka Beach is a beach that has been developing for 4 years. Although it is still relatively new, this beach has been able to bring in a large number of tourists compared to other tourist attractions in Bireuen Regency, with a total of $500-2,000,000$ in 2018. This study analyzed the impact of tourism activities on the economy of the community around the Jangka Beach, Bireuen Regency; specifically the impact on income generation and employment generation. In estimating the economic impact of tourism in the Jangka Beach Area, this study used a formula from the Keynesian Multiplier to calculate the Income Multiplier and the formula from Vanhove to calculate the Employment Multiplier. After the data is entered into both formulas, it will be known the amount of income multiplier and employment multiplier. The results of the study revealed that the total expenditure of tourists who came to the Jangka Coast was Rp. $12,095,000$. Whereas through the analysis conducted, the Keynesian income multiplier value was 2.59; the income multiplier type 1 ratio was 1.09; and the income multiplier type II ratio was 1.14. Meanwhile, the employment multiplier, the multiplier value was 0.0000049 ; which means that this tourist attraction was only able to provide employment opportunities of 0.49 percent of new workers in the tourism sector in addition to the existing workforce.
\end{abstract}

\section{KEY WORDS}

Economic Impact, tourism, income multiplier, employment multiplier.

Marine tourism is one type of tourism that develops in Indonesia. This is because Indonesia is an archipelago with a long coastline and consists of thousands of large and small islands that have tourism potential (Bengen, 2002). This tourism potential really needs to be realized and developed because the tourism sector will provide a significant income for the region (Ismayanti, 2010).

Rapat Koordinasi Nasional Pariwisata III (3rd National Coordination Meeting of Tourism) of 2018 on "Accelerate Investment and Financing for Tourism Sector" stated that tourism has a large investment opportunity and is an option in stabilizing the deficit in Indonesia's trade balance. Tourism is designated as a mainstay sector in generating foreign exchange and a source of income for the region. The government has targeted in 2019 to reach the foreign exchange target of US $\$ 20$ billion, with a target of 20 million foreign tourists and the movement of 275 million local tourists.

Law No.10 of 2009 concerning Tourism states that one of the objectives of tourism is to increase economic growth. With the existence of tourism activities, the people who are in the tourism area will certainly be involved, which will lead to changes in the lives of the community itself, including the economy. This change is a result of the development of tourism to changes in employment and community income, patterns of labor division of, employment and business opportunities (Soekadijo, 2000).

Tourism is a complex social phenomenon and concerns the whol person and has various aspects such as sociological, psychological, economic, ecological, and others. The aspect that draws the most attention and is almost the only aspect that is considered 
important is the economic aspect. On a small scale, tourism development will have a positive impact on the economy of a region (Soekadijo, 2000).

Gampong (village level administration) Jangka Mesjid, Jangka Subdistrict, Bireuen regency has developed a marine tourism objects since 2014. In the initial observation of this study, Keuchik (village head) Gampong Jangka Mesjid explained that at first this beach was not opened for tourism activities because people was worried that there would be violations of Islamic law and customs. But, since this tourist attraction was opened for the public around 2014, this place has been visited by many tourists and provides many benefits to the local community and its surroundings; because currently dozens of family heads make a living by becoming merchants on the Panjang Beach which also accommodates several surrounding local village youth as employees of the canteen, parking attendants and maintaining the security and cleanliness of the beach.

If viewed from the interest of tourist visits, the Gampong Jangka Mesjid maritime tourism activity which has been running for approximately 4 years has the potential to be developed and is believed to be able to improve the economy of the local community. In connection with that matter, it is necessary to conduct a scientific assessment of the Multipier Effect of Marine Tourism objects on the economy of the community in the Gampong Jangka Mesjid in the Jangka Subdistrict of Bireuen Regency.

\section{METHODS OF RESEARCH}

This research was conducted at a marine tourism objects in the Gampong Jangka Mesjid in the Jangka Subdistrict of Bireuen Regency, which is astronomically located at 5 ० $15^{\prime} 20.7^{\prime \prime N ~} 96^{\circ} 46^{\prime} 49.5^{\prime}$ E (Figure 3.1). This research was carried out no later than 3 (three) months, started from October to December 2018.

In this study, the population was domestic tourists who visited the Jangka Beach in Bireuen Regency. Based on interviews with the Keuchik Gampong Jangka Mesjid, the number of visitor could reach 1.500 domestic tourists and local people each day. In this study, the community was only limited to business actors who opened their businesses on Jangka Beach; amounting to 30 businesses consisting of kiosk owners, 1 parking management unit and 3 public toilet units. In addition, 65 people worked in the business unit, consisting of 60 workers in the kiosk business unit, 3 people in the parking management unit and 2 people in public toilets.

The sampling of tourist in this study used a Non-probability sampling. In this technique, samples were taken by not giving the same opportunity for each member to be chosen as a sample and were determined by the researcher's need to answer the research question. The researcher used Accidental sampling, where anyone who to meet with the researcher and the person is considered suitable as a data source (Sugiyono, 2010). Based on the number of tourists ( 1.500 each day) with $5 \%$ level of errors, therefore there were 283 samples that could be taken; based on the number of business actors (32 business actors) with $5 \%$ level of errors, therefore there were 28 samples that could be taken; based on the number of workers (65 workers) with $5 \%$ level of errors, therefore there were 55 samples that could be taken. Based on the description above, the sample in this study can be classified as follows:

Table 1 - Sample Clssification According to Isaac and Michael's Table

\begin{tabular}{clcc}
\hline No. & Population & Total Population $(\mathrm{N})$ & JumlaTotal Samples (Level of error 5\%) \\
\hline 1. & Tourists & 1.500 & 283 \\
2. & Business actors & 32 & 28 \\
3. & Workers & 65 & 55 \\
\hline & Total & 1.597 & 366 \\
\hline
\end{tabular}

Source: Processed Data from Researchers.

In calculating the average expenditure of tourists on the Jangka Beach in Bireuen Regency., the Average Total Cost (ATC) formula was used as follows: 
Average of Total Cost (Average Expenditure $)=\frac{\text { Total Cost }(\text { Tourists' Total Expenditure })}{\text { Quantity }(\text { Number of Samples })}$

The economic impact in this study used Multiplier Effects analysis of the cashflow that occurs. The multiplier value of tourist expenditure could be calculated using the following formula. The multiplier value of tourist expenditure could be calculated using the following formula (META, 2001):

- The Keynesian Income Multiplier; the value created by the addition or reduction of expenses that are multiplied to determine whether there is an addition or reduction for local income. To reflect on the overall impact of additional expenditure, Keynesian is the best method;

- Income Multiplier Ratio; the value obtained from the addition and reduction of direct income from the local economy which has been multiplied to obtain the result of an increase or decrease in total local income.

Keynesian Income Multiplier and Ratio Income multiplier can be projected with the following formula:

$$
\begin{gathered}
\text { Keynesian Income Multiplier }=\frac{D+N+U}{E} \\
\text { Ratio Income Multiplier Tipe I }=\frac{D+N}{D} \\
\text { Ratio Income Multiplier Tipe II }=\frac{D+N+U}{D}
\end{gathered}
$$

Where: $\mathrm{D}=$ Local income obtained directly from $\mathrm{E} ; \mathrm{N}=$ Local income obtained indirectly from $\mathrm{E} ; \mathrm{U}=$ Revenues earned that are induced from $\mathrm{E} ; \mathrm{E}=$ Visitor expenditure.

The value of Keynesian Local Income Multiplier, Type I Ratio Income Multiplier, Type II Ratio Income Multiplier have the following criteria:

- If these values are less than or equal to zero $(\leq 0)$, then the tourist location has not been able to provide an economic impact on tourism activities;

- If the values are between zero and one $(0<x<1)$, then the tourist location still has a low economic impact value;

- If these values are greater than or equal to one $(\geq 1)$, then the tourist location has been able to provide an economic impact on tourism activities.

In analyzing the creation of employment opportunities, the Vanhove (2005) multiplier analysis would be used with the following formula:

$$
E k=\frac{\text { Direct }+ \text { Indirect Employment }}{\text { Expenditure } / \text { spending }}
$$

Where: Ek - Employment Multiplier; Direct - Direct employment generated by the tourism sector; Indirect - Indirect employment generated by the tourism sector; Expenditure - Total money spent by tourists.

The results of the calculation above would show the percentage of employment opportunities for new workers in the tourism sector.

\section{RESULTS AND DISCUSSION}

Direct Income Generation is a tourist expenditure that is carried out when buying goods and services in inns, restaurants, shops, other tourist facilities that produce tourist goods or merchandises to be exported or invested in tourism (Mathieson \& Wall, 1982). Tourists' expenses during their time in tourist locations to meet their needs such as goods or services were impacted on the income of local people who worked at Jangka Beach. 
Tourist expenses that affect the income of the community can be classified into four categories: entrance ticket, food or drink consumption, rental of game equipment and others such as expenses when using the toilet. The expenditure proportion of beach visitors can be seen in Table 2 below:

Table 2 - The Proportion of Tourist Expenditures on Jangka Beach

\begin{tabular}{cccc}
\hline No & Categories & Total Expenditure (Per Visit) & Percentage (\%) \\
\hline 1 & Enterance / Parking Ticket & 926.000 & 7.7 \\
2 & Consumption & 11.087 .000 & 91.7 \\
3 & Equipment Rental / Games & - & 0 \\
4 & Others & 82.000 & 0.7 \\
\hline & Total & 12.095 .000 & 100 \\
\hline
\end{tabular}

Source: Processed Data from Researchers.

In Table 2, it can be seen that tourist expenditure on the Jangka Beach showed considerable cash circulation, especially on holidays and weekends. Based on the data table above, it showed the total tourist expenditure obtained from the results of questionnaires to 283 tourist respondents as much as Rp. 12,095,000.

The largest percentage of tourist expenditure is for consumption purposesas much as $91.7 \%$, while the lowest percentage of tourist expenditure is for rental equipment for game equipment that is equal to $0 \%$. This is due to the fact that the majority of tourists visited the beach were more just to enjoy the beach atmosphere than to enjoy games such as Banana Boat and others.

To obtain the average tourist expenditure, ATC $=T C / Q$ calculation is used. The formula used as follows:

$$
\text { Average of Total Cost (Average Expenditure })=\frac{\text { Total Cost (Tourists' Total Expenditure })}{\text { Quantity (Number of Samples })}
$$

The calculation results showed that the average tourist expenditure per visit was $\mathrm{Rp}$. 42.739,- or rounded up to $\mathrm{Rp}$. 43.000,- per visit.

The number of tourist visits greatly determined the sustainability of a tourist attraction especially in economic activity. The increasing number of tourist visits will certainly increase economic activity triggered by tourist expenditure. Therefore, the transaction flow is even higher. For business owners, revenue from the business unit will be reused to run the business unit as well as for the purchase of raw materials in the vicinity of the Jangka Beach (local).

There are not so many types of businesses on Jangka Beach. The results of the study found out that there are only three types of businesses makes money: kiosks, parking / ticket services and toilets. The details of the income of business owners from tourism on the Jangka Beach can be seen in Table 3 below:

Table 3 - The Revenue of Business Owner on Jangka Beach

\begin{tabular}{ccc}
\hline No & Business Unit or Service & Revenue per Month (Rp) \\
\hline 1 & Kiosk & 672.000 .000 \\
2 & Parking Service & 39.000 .000 \\
3 & Toilet & 2.000 .000 \\
\hline & Total & 713.000 .000 \\
\hline
\end{tabular}

Source: Processed Data from Researchers.

Indirect Income Generation is expenditure caused by the payment of salaries or wages to local employees or tourist companies to fill their shares. Indirect economic impacts can be seen from the proportion of employee wages \& the purchase of raw materials on the income of business owners (Archer, 1976). The details can be seen in Table 4 below: 
Table 4 - Proportion of Business Units

\begin{tabular}{cccc}
\hline No & Components & Proportion on total revenue (\%) & Annotation \\
\hline 1 & Revenue & 42.32 & Local \\
2 & Employee Wages & 10.00 & Local \\
3 & Expenditure needs & 47.68 & Local \\
\hline
\end{tabular}

Source: Processed Data from Researchers.

In Table 4, it can be seen that the proportion for business income was $42.32 \%$ of the operating results used for employee wages and expenditure needs. The next proportion of $10.00 \%$ of income is used by business owner for labor. The highest proportion is on expenditure for raw materials; because according to business owner, raw materials often needs to be stocked in large quantities to avoid erratic price increases and also the items purchased are goods that do not expire quickly. Therefore, the intensity of purchasing is high, while for labor the proportion is low because in some kiosks only employ workers at certain times.

Indirect economic impacts on the Jangka Beach is also seen from the salary received by workers, which then from labor income will be used to buy daily needs and be used for other purposes. The following table is the average labor income in the Jangka Beach based on the questionnaire.

Table 5 - The Income of Local Labor

\begin{tabular}{cccc}
\hline No & Business Unit & Number of Questionnaires & Labor Income per Month (Rp) \\
\hline 1 & Kiosk & 51 & 64.350 .000 \\
2 & Parking / Ticketing & 3 & 3.900 .000 \\
3 & Toilet & 1 & 200.000 \\
\hline & Total & 55 & 68.450 .000 \\
\hline
\end{tabular}

Source: Processed Data from Researchers.

Data in Table 5 showed that there is diversity in the amount of labor income; that diversity depends on the type of work carried out by the community on the Jangka Beach. The total labor incomes were based on the questionnaire that was distributed to 55 respondents at the Jangka Beach, Rp. 68,450,000.

The more tourists visiting the Jangka Beach, the faster the money turnover and the more business opportunities opened for the people on the Jangka Beach. With the opening of business opportunities, it will certainly have a significant impact on the society's economic changes.

Induced Income Generation is an increase in consumer expenditure resulted from additional personal income generated from direct expenditure (Mathieson \& Wall, 1982). In this case, the formation of advanced income is obtained based on expenditures incurred by Jangka Beach's local workers. The types of expenditures incurred by local labor i.e. used for daily needs such as daily consumptions, communication, transportation, social activities and savings. The clearer information about average labor expenditure can be seen in Table 6 below:

Table 6 - Proportion of Labor Expenditures

\begin{tabular}{cccc}
\hline No & Expenditures & Total Amount (Rp) & Percentage (\%) \\
\hline 1 & Daily Consumptions & $34,957,500$ & 51 \\
2 & Communication & $8,240,000$ & 12 \\
3 & Transportation & $5,460,000$ & 8 \\
4 & Social Activities & $2,730,000$ & 4 \\
5 & Savings & $17,062,500$ & 25 \\
\hline
\end{tabular}

Source: Processed Data from Researchers. 
It can be seen from Table 6 that the highest expenditure of local labor was for daily consumption as much as 51\%; and the lowest expenditure was for social activities only $4 \%$. From all 51 samples there is no expenditure on household needs or education costs, because the average workforce is young and has no family (single), and for those who are married they usually still rely on the income of husbands who work outside the Jangka Beach to increase their income.

Income Multiplier Value from tourist expenditure that occurs in the Jangka Beach area can be measured using multiplier effects from the cash flow. The following formulas were used to calculate the Multiplier Effect of Jangka Beach tourism activities. namely:

There are two multiplier values based on META (2001) in measuring Income Multiplier,

- Keynesian Income Multiplier that shows how tourist expenditure has an impact on increasing local people's income. The Keynesian Income Multiplier (KIM), calculated using the formula:

$$
\text { Keynesian Income Multiplier }=\frac{\mathrm{D}+\mathrm{N}+\mathrm{U}}{E}
$$

Where: $D=$ total income of business owner; $N=$ total income of workers; $U=$ total expenditure of labor's daily consumption; $E$ = total expenditureof tourist; If the value is entered, the result showed as follows:

$$
K I M=\frac{713.000 .000+68.250 .000+34.855 .500}{314.470 .000}=2.59
$$

This means that every time a Rp. 1 increases in tourist expenditure, it will have a direct impact of Rp. 2.59, - rupiah on the economy of the community.

- Ratio of Income Multiplier (RIM), which shows how much direct impact, was felt from tourist expenditure which has a direct impact on the overall local economy. For more details, the analysis of the Income Multiplier can be seen below:

$$
\text { RIM Type } I=\frac{D+N}{D}=1.09
$$

This means that every Rp. 1 increases of business unit income will result in an increase of Rp. 1.09 rupiah on the income of the surrounding workers (in the form of business owner income and labor wages).

$$
\text { RIM Type II }=\frac{D+N+U}{D}=1.14
$$

This means that every Rp. 1 increases in the reception of a business unit, it will result in an increase of Rp. 1.14 in the income of the owner of the business unit, labor income, and

\begin{tabular}{|c|c|c|}
\hline No & Criteria & Value \\
\hline 1 & Keynisian Income Multiplier & 2.59 \\
\hline 2 & Income Multiplier Ratio Type I & 1.09 \\
\hline 3 & Income Multiplier Ratio Type II & 1.14 \\
\hline
\end{tabular}
labor consumption expenditure at the local level.

For more details, the value of the Multiplier Effect can be seen in Table 7 below:

Table 7 - Multiplier Effect Value

Source: Processed Data from Researchers.

To determine whether tourism activities on the Jangka Beach have an impact on the economy, the three types of values obtained need to be matched with the criteria as explained by Marine Ecotourism for Atlantic Area (2001). If the value is between zero and 
one $(0<x<1)$, the tourist area has an impact on the economy even though it's low. If the value is greater than or equal to one $(\geq 1)$, the tourist area has contributed to the economy in the form of tourism activities.

Based on the results in Table 7, the obtained value of the three Multiplier Effect criteria is greater than one $(>1)$, therefore it can be concluded that the existence of the Jangka Beach Marine Tourism has actually had an economic impact on the economy of the community, which includes direct impacts, indirect impact and further impact (in the form of income of the owner of the business unit, local labor income and income for local level consumption).

To analyze the formation of employment, multiplier analysis wil be used (Vanhove, 2005) with the following formula:

$$
E k=\frac{\text { Direct }+ \text { Indirect Employment }}{\text { Expenditure } / \text { spending }}
$$

Where: Ek - Employment Multiplier; Direct - Direct employment generated by the tourism sector; Indirect - Indirect employment generated by the tourism sector; Expenditure - Total money spent by tourists.

The formula will be used to observe the results of the sum of the number of employees who work with the expenditure of tourists on the Jangka Beach.

Table 8 - Number of employees worked on the Jangka Beach

\begin{tabular}{|c|c|c|}
\hline No & Division & Employees \\
\hline \multicolumn{3}{|c|}{ Direct Employment } \\
\hline 1 & Ticketing/Parking & 3 personnel \\
\hline 2 & Kiosk & 51 personnel \\
\hline 3 & Toilet & 1 personnel \\
\hline Total & & 55 personnel \\
\hline \multicolumn{3}{|c|}{ Indirect Employment } \\
\hline 1 & Janitorial Service & 2 personnel \\
\hline 2 & Secirity & 2 personnel \\
\hline Total & & 4 personnel \\
\hline
\end{tabular}

Source: Processed Data from Researchers.

Based on the table above, it can be seen that there were 55 employees who interact directly with tourists; and 4 employees who did not interact directly with tourists. Whereas for data on total tourist expenditure as much as Rp 12,095,000-. This expenditure is obtained during tourists spent their time on the Jangka Beach.

If the value is entered, the result is as follows:

$$
E k=\frac{\text { Direct }+ \text { Indirect Employment }}{\text { Expenditure } / \text { spending }}=0.0000049
$$

The results of the analysis can be concluded that:

- If every tourist spends Rp. 1, it can give the effect of a job opportunity as much as 0.0000049 percent of the workers in the Jangka Beach marine tourism object;

- If the tourists who visit the Jangka Beach marine tourism object and spent Rp 100.000 per visit, it can provide employment opportunities of 0.49 percent of new workers in the field of tourism; means that there are still very few opportunities to open employment opportunities for new workers in tourism in addition to existing workers. 


\section{CONCLUSION AND RECOMMENDATIONS}

The Marine Tourism Activities of Jangka Beach in Bireuen Regency have had a large economic impact on local communities. The economic impacts of tourism activities were direct impacts, indirect impacts, and further impacts measured by the value of multiplier effects, where from the results of this study the income multiplier effect value is greater than one (> 1), i.e. 2.59 for the Keynesian Income Multiplier; 1.09 for the Income Multiplier Ratio Type I; and 1.14 for the Income Multiplier Ratio for Type II.

The percentage of employment opportunities for new workers of Jangka Beach Marine Tourism activity in Bireuen Regency was still very small, this was indicated by the multiplier effect, where from the results of this study, the Employment Multiplier value was 0.0000049 , means that it only gives employment opportunities of 0.49 percent of the new workers in tourism in addition to the existing workforce.

\section{REDERENCES}

1. Anonim. 2009. Undang-Undang Republik Indonesia No. 10 Tahun 2009. Tentang Kepariwisataan. Jakarta

2. Antonio, K.C. 2017. Tourism multipliers in the Mexican economy. Journal of Tourism, Heritage \& Services Marketing: Mexico.

3. Archer, B.H. 1976. The Anatomy of a Multiplier, Regional Studies.

4. Arikunto, S. 2010. Prosedur Penelitian Suatu Pendekatan Praktik. Jakarta: Rineka Cipta

5. Aryanto R. 2003. Environmental marketing pada ekowisata pesisir: Menggerakan ekonomi rakyat daerah otonom. Makalah Falsafah Sains. Institut Pertanian. Bogor.

6. Bengen, D.G. 2002. Ekosistem and sumberdaya alam pesisir and laut serta prinsip pengelolaannya. Sinopsis. Pusat Kajian Sumberdaya Pesisir and Lautan. IPB

7. Bungin, Burhan, 2010. Pengantar Pariwisata. Grasindo, Jakarta.

8. Cooper. 1998. Tourism Planning: Basics Concept Cases. Singapore.

9. Ecotourism in The EU Atlantic Area. University of The West of England, Bristol.

10. Glasson, J, 1990. Pengantar Perencanaan Regional (An Introduction to. Regional Planning), Terjemahan Paul Sitohang, FE-UI, Jakarta.

11. Gunn, Clare A. 1993. Tourism Planning, Basic, Concepts, Cases. Washington DC: Taylor and Francis.

12. Hery, S.C. 2018. Tourism Economic Impact of South Lampung Regency. Journal of Indonesian Tourism, Hospitality and Recreation. Tourism Destination Studies Department Bandung Institute of Tourism

13. Inskeep, E. 1991, Tourism Planning: An Integrated and Sustainable Development Approach, Van Nostrand Reinhold, New York.

14. Ismayanti. 2010. Pengantar Pariwisata. Jakarta: PT Gramedia Widisarana. Indonesia.

15. Jeetesh, K \& Kashif, H. 2014. Evaluating tourism's economic effects: Comparison of different approaches. Elsevier.

16. Kodhyat, H. 2003. Sejarah Pariwisata and Perkembangannya di Indonesia. Gramedia Widiasarana Indonesia. Jakarta.

17. Marine Ecotourism for Atlantic Area (META-Project). 2001. Planning for Marine

18. Marpaung, H. 2002. Pengetahuan Kepariwisataan. Alfabeta. Bandung.

19. Mathieson \& Wall, 1982. Tourism: Economic, Physical and. Social Impact. New York.

20. Muhammad. I., 2017. Multiplier Effect Industri Pariwisata Candi Muara Takus Terhadap Perekonomian Masyarakat di Kecamatan XII Koto Kampar Kabupaten Kampar.

21. Rakornas Pariwisata III, 2018. "Accelerate Investment and Financing for Tourism Sector". Dian Ballroom Hotel Raffles Jakarta. ( http://www.tribunnews.com/kilaskementerian/2018/09/27/kebutuhan-investasi-pariwisata-dipetakan-di-rakornaspariii2018.) Tanggal akses: 20 Desember 2018.

22. Sekaran. 2011. Research Methods for business Edisi I and 2. Jakarta: Salemba Empat.

23. Sharpley, Richard, 2006. Travel and Tourism. New York: SAGE Publications 
24. Soekadijo, R G. 2000. Anatomi Pariwisata: Memahami Pariwisata sebagai. Systemic Linkage. Jakarta: PT. Gramedia Pustaka Utama.

25. Spillane, J. J. 2009. Ekonomi Pariwisata, sejarah and prospeknya. Yogyakarta: Kanisius

26. Stephen. P. 2015. The economic impact of tourism in SIDS. Annals of Tourism Research. Elsevier.

27. Subana and Sudrajat. 2005. Dasar-Dasar Penelitian Ilmiah. Pustaka Setia. Bandung.

28. Sugiyono. 2010. Metode Penelitian Pendidikan Pendekatan Kuantitatif, kualitatif, and R\&D. Bandung: Alfabeta.

29. 2012. Metode Penelitian Pendidikan Pendekatan Kuantitatif, kualitatif, and R\&D. Bandung: Alfabeta.

30. Suwantoro, 2009. Dasar-Dasar Pariwisata. Penerbit Andi Yogyakarta.

31. Umi. N. 2007. Riset Manajemen Sumber Daya Manusia Aplikasi \&. Contoh Perhitunganya. Jakarta. Agung Media.

32. UNWTO. 2014. Measuring Employment in the Tourism Industries. UNWTO: Spain.

33. [UNEP] United Nation Environment Programme-International Environmental Technology Centre. 2002. Tourism in the Green Economy. Boston: Butterworth-Heinemann.

34. Vanhove. 2005. The Economics of Tourism Destionations. Oxford: ButterworthHeinemann.

35. Wan. C. 2009. Introduction to Tourism. Hongkong: Wu Chung House.

36. Yoeti, Oka A. 2008. Pengantar IImu Pariwisata. Bandung: Angkasa. 